\title{
Effects of insect diets on the gastrointestinal tract health and growth performance of Siberian sturgeon (Acipenser baerii Brandt, 1869)
}

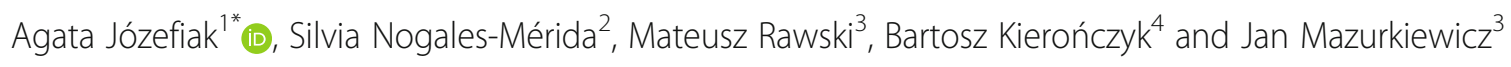

\begin{abstract}
Background: Insects in the fish diet are a natural source of protein, fat, and other nutrients. These meals are considered an ecological replacement for fishmeal to improve growth parameters. The application of insect meals to fish diets has been studied, especially in continental fish. Data regarding the effects of insect meals on the gut health of Siberian sturgeon are not available. This study investigated the effects of full-fat Hermetia illucens (HI) and Tenebrio molitor (TM) meals on the gut health of juvenile Siberian sturgeon. Growth performance, gastrointestinal tract (GIT) histomorphology and the microbiome composition of juvenile Siberian sturgeon were analyzed.
\end{abstract}

Results: The inclusion of insect meals did not affect the growth performance or the survival rate. In the gastrointestinal tract histomorphology, a reduction in the mucosa thickness with the HI treatment was observed. In contrast, fish fed the TM diet had an increase in the thickness of the muscular layer. There were no observed significant differences in villus height among treatments. The analysis of the selected microbiota populations in the Siberian sturgeon gastrointestinal tract showed that insect addition affected the composition of the microbiome. The greatest effect on bacterial populations (Clostridium leptum subgroup, Enterobacteriaceae, Clostridium coccoides - Eubacterium rectale cluster, Aeromonas spp., Bacillus spp., Carnobacterium spp., Enterococcus spp. and Lactobacillus group) was observed with the HI diet $(P<0.05)$. The TM-based diet increased counts in the following bacterial groups: Clostridium coccoides - Eubacterium rectale cluster, Bacillus spp., Carnobacterium spp., and Enterococcus spp. In contrast, the TM diet decreased the total number of bacteria. The TM diet did not significantly affect the Clostridium leptum subgroup, Enterobacteriaceae, Aeromonas spp. or the Lactobacillus group.

Conclusions: Fish meal replacement by the inclusion of 15\% of full-fat Hermetia illucens and Tenebrio molitor (15\%) meals did not affect the growth performance, survival rate or villus height of juvenile Siberian sturgeon. The present study suggests that an H. illucens-based diet positively affects the gut microbiota composition and intestinal morphology of juvenile Siberian sturgeon without negative changes in the villus height.

Keywords: Siberian sturgeon, Insect meals, Fish nutrition, Microbiology, Tenebrio molitor, Hermetia illucens

\footnotetext{
*Correspondence: agata.jozefiak@up.poznan.pl

1 Department of Preclinical Sciences and Infectious Diseases, Poznan

University of Life Sciences, Wołyńska, 35, 60-637 Poznań, Poland

Full list of author information is available at the end of the article
}

(c) The Author(s). 2019 Open Access This article is distributed under the terms of the Creative Commons Attribution 4.0 International License (http://creativecommons.org/licenses/by/4.0/), which permits unrestricted use, distribution, and reproduction in any medium, provided you give appropriate credit to the original author(s) and the source, provide a link to the Creative Commons license, and indicate if changes were made. The Creative Commons Public Domain Dedication waiver (http://creativecommons.org/publicdomain/zero/1.0/) applies to the data made available in this article, unless otherwise stated. 


\section{Background}

The Siberian sturgeon (Acipenser baerii, Brandt, 1869) is one of the most valuable fish species in aquaculture. It is farmed for the production of caviar and high meat quality for human consumption [9, 10]. This species, as well as others in the family Acipenseridae, are known to eat insects, mainly chironomids (Chironomidae) and mayflies (Ephemeroptera) $[25,28,45]$, in the wild. The primary prey of shovelnose sturgeon (Scaphirhynchus platorynchus) and pallid sturgeon (S. albus) are the aquatic larvae of Trichoptera, Ephemeroptera, and Diptera [31]. Insects in the fish diet are a source of protein, lipids, and bioactive compounds, including vitamins, chitin, and antimicrobial peptides (AMPs), which are known to improve the animal immune system and can modulate the microbiota composition of the gastrointestinal tract [38-41, 61]. In addition, certain insect meals can also provide minerals such as calcium, as with $H$. illucens, or phosphorus, as with Musca domestica [51], although the contents of these nutrients depend on the insect diet [30].

Although juveniles consume insects in natural conditions, in aquaculture, their diets contain fishmeal (FM) as the main source of protein $[15,56]$. However, the use of FM is an environmental concern due to the high amount of wild fish captured for FM production [34]. Many alternative protein sources have been studied for general fish nutrition to replace fishmeal. The most available are plant meals. However, some plant meals resulted in growth depression, i.e., soybean meal (SBM) [43], soy protein concentrate, and rapeseed meal [55]. Other meals, such as sesame oil cake and corn gluten [37], caused a reduction in growth performance in cases with inclusion levels higher than $24 \%$ and was the same with wheat gluten [4]. This may be partially explained by the presence of antinutritional factors such as phytic acid, lectins, saponins, protease inhibitors, glucosinolates, and tannins [18]. Additionally, to achieve optimal growth performance using plant meals, it is necessary to use essential amino acid supplementation [86]. Thus, the use of plant meals is considered a cause of health problems in sturgeon $[46,47]$.

Recently, insect meals have been promoted to replace FM and/or SBM for fish nutrition, such as the larvae of green bottle fly (Lucilia sericata) used in gilthead seabream (Sparus aurata) meal [11] or superworm (Zophobas morio) for Nile tilapia, Oreochromis niloticus [36]. One of the most studied insects as an additive for fish nutrition is the mealworm (Tenebrio molitor), which has been evaluated in rainbow trout (Oncorhynchus mykiss) [5], catfish (Clarias gariepinus) [60], common catfish (Ameiurus melas) [73], guppies (Poecilia reticulata) [2], and European seabass (Dicentrarchus labrax) [21]. The second is the black soldier fly (Hermetia illucens), which has also been evaluated in rainbow trout (Oncorhynchus mykiss) [14, 70, 80], Nile tilapia [58], common carp (Cyprinus carpio) [48] and European seabass [50]. However, in the available literature, there is no information about the application of mealworm and/or black soldier fly meals for sturgeon nutrition.

Some of the most important factors of animal health include growth performance parameters and gastrointestinal tract (GIT) conditions. There are many data on the impact of nutrition on the gastrointestinal microbiota and gut health $[6-8,11,16,20,26,30,40,72]$. Intestinal diseases can develop as an effect of unbalanced diets resulting in disturbances in the homeostasis of the GIT microbiome.

Therefore, the current study was designed to evaluate the effects of partial fishmeal replacement with full-fat mealworm and black soldier fly meals for Siberian sturgeon with regard to fish performance parameters, survival rate, GIT microbiota composition and gut histomorphology.

\section{Results}

\section{Growth and feed efficiency}

There were no significant differences among the treatments with regard to BWG, SGR, FCR, and PER at the end of the experimental period $(P>0.05)$. The survival rate at the end of the trial was $100 \%$ for all the treatments (Table 1).

\section{Histomorphology}

The mucosa thickness and muscular layer, but not villus height, (Fig. 2) were affected by dietary treatments $(P<$ $0.05)$. The HI diet caused the highest reduction in mucosal thickness $(118 \mu \mathrm{m})$ compared to that of the fish fed the control diet $(154 \mu \mathrm{m})$ and the fish fed the T. molitor $(145 \mu \mathrm{m})$ diet $(P<0.05)$. In contrast, the $T$. molitor diet

Table 1 Growth and feed utilization parameters of Siberian sturgeon (Acipenser baerii Brandt) fed three experimental diets in which fishmeal was partially replaced with full-fat Hermetia illucens meal (15\%) and Tenebrio molitor meal (15\%) for 60 days. Data are presented as the mean \pm standard error

\begin{tabular}{lllllll}
\hline & \multicolumn{2}{l}{ Diets } & & SEM & $\begin{array}{l}p \text { - } \\
\text { value }\end{array}$ \\
\cline { 2 - 4 } & CT & TM & HI & & 0.4363 \\
\hline IBW (g) & 636.67 & 648.33 & 646.67 & 6.45 & 0.1178 \\
FBW (g) & 1196.81 & 1195.04 & 1194.81 & 16.44 & 0.9217 \\
BWG (g) & 546.67 & 553.33 & 555.00 & 7.7700 & 0.927 \\
FCR $^{a}$ & 1.47 & 1.47 & 1.48 & 0.03 & 0.9356 \\
SGR $^{\text {b }}$ & 1.03 & 1.03 & 1.03 & 0.02 & 0.9515 \\
PER $^{c}$ & 1.52 & 1.50 & 1.52 & 0.0100 & 0.8907 \\
\hline
\end{tabular}

All values are means of triplicate cases $(n=3)$. Different alphabetic superscripts in the same row indicate significant differences at $a<0.05$ $I B W$ initial body weight, $F B W$ final body weight, $B W G$ body weight gain

${ }^{a}$ Feed conversion ratio, $F C R=$ feed offered $(g) /$ biomass gain $(g)$

${ }^{\mathrm{b}}$ Specific growth rate $\left(\%\right.$ day $\left.^{-1}\right), \mathrm{SGR}=100 \mathrm{x} \ln$ (final weight/initial weight)/days.

${ }^{c}$ Protein efficiency ratio, PER = biomass gain $(\mathrm{g}) /$ protein offered $(\mathrm{g})$ 
increased the muscular layer thickness $(300 \mu \mathrm{m})$ in comparison to that in the fish fed the $\mathrm{HI}$ diet $(262 \mu \mathrm{m})$ and the control diet $(243 \mu \mathrm{m})(P<0.05)$.

\section{Microbiota analysis in the gastrointestinal tract (GIT)}

The gut microbiota analysis of juvenile Siberian sturgeon fed with $\mathrm{HI}$ and TM revealed statistically significant $(S<0.05)$ changes in the following taxonomic groups: the Clostridium leptum subgroup, Enterobacteriaceae, Clostridium coccoides - Eubacterium rectale cluster, Aeromonas spp., Bacillus spp., Carnobacterium spp., Enterococcus spp. and the Lactobacillus group (Table 2). The HI-based diet group had the highest total number of bacteria in GIT digesta. Compared to that of the CT group, the HI group had significantly increased bacterial counts observed for all analyzed groups of GIT microbiota, including the Clostridium leptum subgroup, Enterobacteriaceae, Clostridium coccoides - Eubacterium rectale cluster, Aeromonas spp., Bacillus spp., Carnobacterium spp., Enterococcus spp. and the Lactobacillus group, which changed significantly according to feed type $(P<0.05)$ (Table 2$)$. The TM-based diet increased counts in the following groups of bacteria: Clostridium coccoides - Eubacterium rectale cluster, Bacillus spp., Carnobacterium spp., and Enterococcus spp. In contrast, the TM diet decreased the total number of bacteria. No statistical effect of the TM diet compared to the CT diet was observed in the case of the Clostridium leptum subgroup, Enterobacteriaceae, Aeromonas spp. and the Lactobacillus group.

\section{Discussion}

To the authors' knowledge, the present study is the first attempt to replace fishmeal with full-fat $H$. illucens and $T$. molitor meals for Siberian sturgeon nutrition. Currently, the main source of protein for farmed sturgeon is fishmeal with partial inclusion of plant meals, especially soybean meal [12, $35,74,83]$. However, the present results suggest that insect meals can also substitute for FM in Siberian sturgeon diets without negative effects on growth performance. Moreover, considering the $15 \%$ inclusion rate, $H$. illucens meal represented a 30\% replacement of FM protein in the diet, and in the case of T. molitor, a $40 \%$ replacement. Similar values have been obtained in experiments conducted with $O$. mykiss [5], C. gariepinus [60] and C. carpio [48], which also consume insects as part of their natural diet.

It is well documented that dietary factors may affect the intestinal morphology, even changing the length of the gut as well as the internal structures, such as the elongation or shortening of the villi, the modification of the goblet cells [76], and the migration of inflammatory cells [83]. Consequently, this affects animal gut health [57]. This could be the case in the muscularis layer when it thickens, which has been associated with the improvement of digestion and absorption [77]. The opposite effect is associated with a decrease in motility in the digestive tract as a degenerative process in aging [78].

Therefore, in the current experiment, modification of the GIT structures due to the inclusion of full-fat insect meals in the Siberian sturgeon diet could be beneficial to the animals by improving the function of the GIT. Interestingly, changes in GIT structures, particularly mucosal and muscular layer thickening, indicate the adaption of the GIT to insect-based diets, which are much closer to natural conditions [28].

The structure of the digestive tract differs according to fish species. The differences develop in the embryonic stage and are the first factor in gastrointestinal bacterial community formation. In general, Aeromonas, Pseudomonas, Clostridium and Bacteroides predominate in fish GITs. However, Bacteroides appears late in the gastrointestinal tract of fish, as late as on the 44th day after hatching, but they become predominant in the intestines of adult fish.

In fish as well as in other vertebrates, gastrointestinal microbiota populations strictly correlate with diet and

Table 2 Selected intestinal microbiota populations of Siberian sturgeon digesta at the end of the experimental period

\begin{tabular}{|c|c|c|c|c|c|}
\hline \multirow[t]{2}{*}{ Target } & \multicolumn{3}{|l|}{ Diets } & \multirow[t]{2}{*}{ SEM } & \multirow{2}{*}{$\begin{array}{l}p- \\
\text { value }\end{array}$} \\
\hline & $\overline{C T}$ & $\mathrm{HI}$ & TM & & \\
\hline \multicolumn{6}{|l|}{ LOG CFU/g of digesta } \\
\hline Total number of bacteria & $8.27^{\mathrm{b}}$ & $8.87^{\mathrm{a}}$ & $8.14^{c}$ & 0.0479 & 0.0001 \\
\hline Clostridium leptum subgroup & $7.66^{\mathrm{b}}$ & $8.12^{\mathrm{a}}$ & $7.73^{\mathrm{b}}$ & 0.0349 & 0.0001 \\
\hline Enterobacteriaceae & $7.69^{\mathrm{b}}$ & $7.94^{\mathrm{a}}$ & $7.73^{b}$ & 0.0301 & 0.0004 \\
\hline Clostridium coccoides - Eubacterium rectale cluster & $7.40^{\mathrm{b}}$ & $7.66^{\mathrm{a}}$ & $7.55^{\mathrm{a}}$ & 0.0287 & 0.0008 \\
\hline Aeromonas spp. & $8.10^{\mathrm{b}}$ & $8.45^{\mathrm{a}}$ & $8.13^{\mathrm{b}}$ & 0.03 & $<.0001$ \\
\hline Bacillus spp. & $8.02^{c}$ & $8.42^{\mathrm{a}}$ & $8.25^{\mathrm{b}}$ & 0.03 & $<.0001$ \\
\hline Carnobacterium spp. & $7.97^{c}$ & $8.34^{\mathrm{a}}$ & $8.20^{b}$ & 0.03 & $<.0001$ \\
\hline Enterococcus spp. & $7.81^{c}$ & $8.21^{\mathrm{a}}$ & $8.03^{b}$ & 0.03 & $<.0001$ \\
\hline Lactobacillus group & $7.39^{b}$ & $8.19^{\mathrm{a}}$ & $7.96^{\mathrm{ab}}$ & 0.12 & 0.0205 \\
\hline
\end{tabular}

All values are means of nine cases $(n=9)$. Different letters indicate significant differences between treatments $(P<0.05)$ 
GIT functions, as well as the health status and performance of the animals. H. illucens and T. molitor are rich sources of small proteins and peptides with balancing effects on GIT microbiota [39]. They are known to act as prebiotics, improving the gut absorptive area [27], selectively stimulating the growth of beneficial bacteria over detrimental pathogenic bacteria [27], fungi and viruses [85]. They also improve the oxidative status of fish [27], promoting the colonization of beneficial gut microbiota. In addition, chitin in the exoskeleton of insects has antioxidant activity in low amounts as well as antifungal and antiviral properties [3]. Additionally, GIT morphology and animal growth are dependent on the gut bacterial community [66].

All of the analyzed bacterial groups consist of important bacterial populations of the GIT microbiome. Moreover, Lactobacillus, Enterococcus, Carnobacterium, Bacillus, Aeromonas and Clostridium are some of the most common probiotics used in aquaculture practices, which suggests that insect meals with the above bacterial strains may provide health benefits for Siberian sturgeon breeding [59].

Phylogenetic analyses of the $16 \mathrm{~S}$ rRNA genes from the Siberian sturgeon gut microbial communities showed that the most abundant phyla detected in the fish hindguts were Fusobacteria, Firmicutes and Proteobacteria [22, 23]. Fusobacteria are represented mainly by Fusobacterium [22, 23]. The most frequent classes within the Firmicutes phylum were Clostridia and Bacilli [22, 23]. The most dominant bacterial populations in the Proteobacteria gamma subclass was the genus Aeromonas and the family Enterobacteriaceae [23, 32]. Aeromonas are frequently identified in carnivores, omnivores and planktivores and make up natural and important parts of the fish gut microbial community [13]. The genus Aeromonas cover a diverse group of gram-negative bacteria that are commonly present in aquatic environments and soil, as well as in various animals and humans. Aeromonads are ubiquitous bacteria in fresh water and have been identified as potential pathogenic bacteria that cause fish skin changes and a variety of human diseases associated with intestinal and extraintestinal infections [65]. Aeromonas is also a potential foodborne pathogen for humans. However, the epidemiology of human disease is still unclear; therefore, they need to be considered with regard to public health [62]. A study performed on Arctic charr, Salvelinus alpinus, showed that a commercial diet changed gut microbial diversity $[71,72]$. In the GIT of fish maintained in freshwater and seawater, approximately $55 \%$ of the bacterial flora was Enterobacteriaceae. However, when the fish were fed a commercial diet, the dominant microflora in feces were Aeromonas and Pseudomonas [72]. According to the results of other studies, Aeromonas and Lactobacillus bacteria predominate in the intestinal microbiome of fish inhabiting natural water bodies, whereas Enterobacteriaceae, which comprise up to $50 \%$ of all bacteria, are prevalent in the microbiota of farmed fish that are fed artificial food [20]. However, modification of the bacterial community is an important factor for disease prevention and treatment.

In the current study, Aeromonas spp. increased with the HI treatment, while a TM diet did not statistically change the aeromonad population, which may suggest that HI (15\%) may change the GIT microbial diversity of juvenile Siberian sturgeon, leading to aeromonad domination in relation to Enterobacteriaceae.

High values of the Enterobacteriaceae family were also observed in the digesta of fish fed the HI diet. This could be explained according to the findings of Borrelli et al. [8], who noted that $H$. illucens significantly increased the diversity within the microbial population. In addition, the presence of bacteria that belong to the Enterobacteriaceae family is considered normal in fish farmed near human populations [80-82].

Clostridium leptum subgroups are known to produce butyrate products, which contribute to human intestinal health $[44,52]$. Changes in the Clostridium leptum subgroup is an indicator of the health status of the gut. Species of this genus produce organic acids, including butyrate, acetate, lactate, or formate, but not propionic and succinic acids, as primary products of dietary fiber fermentation. Reduction in the number and diversity of the Clostridium leptum subgroup is observed in human Crohn's disease and ulcerative colitis [44], which could contribute to reduced short-chain fatty acids. The abundance of $E$. rectale and Clostridium leptum indirectly affects epithelial cell structure and function, particularly in the lower regions of the GIT [52]. In our study, the HI additive significantly increased the counts of Clostridium leptum, while no significant differences were observed in the TM diet group and the control group. Increased Clostridium counts were also observed in the Clostridium coccoides - Eubacterium rectale cluster in the HI and TM diets.

Another potentially positive effect on gut health status is an increase in the number of Bacillus spp., which one of the most common probiotics used in aquaculture [23]. A study performed by Ghosh et al. (2002) identified different members of the Bacillus genus as B. circulans, $B$. pumilus and B. cereus [24]. The study of bacterial isolates indicated that they could adapt to a wide range of temperatures and $\mathrm{pH}$. Autochthonous bacteria that remained present in the GIT possessed enzymatic activity that might have had beneficial effects on fish health [24]. The effect of endogenous Bacillus circulans was also investigated by Geraylou et al. [23] in a study performed on juvenile Siberian sturgeon (Acipenser baerii). The authors identified Lactococcus lactis subsp. lactis and Bacillus circulans isolated from the hindgut of juvenile Siberian sturgeon as a new class of candidate prebiotics [23]. Moreover, several studies have demonstrated the immunomodulatory 
effects of Bacillus spp., including the improvement of phagocytosis in $C$. catla and the resistance to salinity, temperature, ammonia and $\mathrm{pH}$ changes by the larvae of Acipenser percicus $[17,23]$. In the current study, Bacillus spp. were increased with HI and TM treatments, which may suggest improvement of the positive bacterial barrier against fish pathogens and may enhance host defense immunomodulatory effects.

Another bacterial group isolated from the gastrointestinal tract that produces inhibitory substances against bacterial fish pathogens was Carnobacterium spp. Lactic acid bacteria (LAB) were isolated from fish and screened for bacteriocin production and immunomodulatory effects [64]. The study by Pilet et al. (1995) indicated that Carnobacterium piscicola and Carnobacterium divergens isolated from fish could produce bacteriocins active against Listeria monocytogenes [64]. Bacteriocin-producing bacterial strains belonging to the genera Carnobacterium and Lactococcus and Enterococcus were isolated from fish intestines, smoked fish and even marine fish. The genus Enterococcus includes more than 30 species. However, the most prevalent species in foods are Enterococcus faecalis and Enterococcus faecium. Some enterococci have bacteriocinogenic potential and are capable of inhibiting the growth of pathogenic bacteria.

In our study, the bacterial counts of Carnobacterium spp., Enterococcus spp. and the Lactobacillus group were significantly different. The results of the TM treatment on $\mathrm{LAB}$ bacteria indicated an increase in Carnobacterium spp. and Enterococcus spp., while no differences were indicated in the Lactobacillus group of bacteria. This may suggest a greater increase in $\mathrm{LAB}$ in the $\mathrm{HI}$ diet than that in the TM diet. However, both HI and TM diets caused an increase in probiotic bacterial populations to have a healthy effect on juvenile Siberian sturgeon.

Another possible cause could be attributed to dietary fat and carbohydrates, which are considered major factors for modification of the gut microbial community profile. Many studies reported that a high-fat diet increased the population of Enterobacteriaceae and Lactobacillus spp. [29, 49]. These results were also confirmed in our studies. The diet with $\mathrm{HI}$ had a higher fat content with greater Enterobacteriaceae and Lactobacillus group populations than did the TM diet, which did not cause changes in the Enterobacteriaceae and Lactobacillus bacterial communities. The effects of different lipid and carbohydrate contents in the diets were observed by Ring $\varnothing$ and Olsen [71] in Salvelinus alpinus fed with different levels of carbohydrates/lipids. Nevertheless, as Borrelli et al. (2017) noted, the acquired microbial richness may potentially provide further metabolic capabilities to the host, which could be the case for Siberian sturgeon fed a diet with HI [8]. In the case of the TM diet, the effects of this insect meal seemed to be similar to those of the CT diet. However, if we examine growth performance and microbiota, these values were not enough to cause health problems for Siberian sturgeon or altered weight gain during the experimental period.

In general, the increase of bacterial populations observed in this study should be considered a positive effect that may improve fish health. Intestinal microbiota play an indispensable role in the origin of gut health. Host microbiota homeostasis is an important factor in the first line of defense against pathogens. Moreover, diversification of the microbial population of the fish GIT is very important in establishing health status, and it can diversify enzymatic potential to interfere with host metabolism [20]. Gastrointestinal bacteria take part in nutrient digestion to provide the host enzymes, amino acids and vitamins [49]. Furthermore, the diversity of symbiotic gut microflora might also be a potential mechanism for the regulation of bacterial homeostasis by IgA. IgA is the major antigen-specific mechanism by which the immune system directly interacts with and influences the luminal microbiota and supports host-microbiota homeostasis [63].

Additionally, the insect meals seemed to improve the relationship between GIT morphology and the gut microbiome, promoting the health of the fish with survival and growth performance similar to those fed with fishmeal. That was not the case in S. aurata fed with a mix of plant meal, which seriously affected the survival of the animals; Estruch et al. (2015) associated this mortality with certain bacterial consortia within the plant meal diet [16].

\section{Conclusion}

The current preliminary study demonstrated that the inclusion of $15 \%$ of $H$. illucens and T. molitor full-fat meals in Siberian sturgeon diets resulted in the same growth performance and feed efficiency as those obtained with fishmeal. The HI-based diet caused certain modifications of the intestinal histomorphology and microbiology, namely, a reduced thickness of mucosa, increased muscle layer thickness and an increase in the total number of bacteria in the following groups: the Clostridium leptum subgroup, Enterobacteriaceae, Clostridium coccoides - Eubacterium rectale cluster, Aeromonas spp., Bacillus spp., Carnobacterium spp., Enterococcus spp. and the Lactobacillus group.

In contrast, the TM diet increased the thickness of the muscular layer. Both the HI and TM diets did not elicit significant differences in villus height. There was no effect of the TM diet on the intestinal population of the Clostridium leptum subgroup, Enterobacteriaceae, Aeromonas spp., the Lactobacillus group, and Enterococcus spp. Changes in microbiota composition and intestinal morphology contributed to the gut health status of Siberian sturgeon. Moreover, it could be concluded that the $H$. illucens-based diet has a higher potential for modulation of the GIT microecosystem compared to the T. molitor diet. However, these changes could be 
attributed to other factors that did not affect the performance of the fish during the experiment and need further microbiological studies. In addition, other trials should be conducted in Siberian sturgeon fed different levels of insect meals to find the maximum amount that the animal could accept without negatively affecting the feed efficiency parameters and health. In addition, we should determine whether the morphological changes would be harmful to animal health or only an adaptation to the insect meal.

The insect diet including Hermetia illucens (15\%) and Tenebrio molitor (15\%) did not affect the growth performance, survival rate or villus height and can be considered as a partial replacement of other protein sources in juvenile Siberian sturgeon. The results of the present study indicated that an insect diet including $H$. illucens can have a positive effect on the gut microbiome composition and intestinal morphology of juvenile Siberian sturgeon.

\section{Methods}

\section{Experimental diets}

Three extruded isonitrogenous $(53.20 \pm 0.12 \% \mathrm{CP})$ and isoenergetic $(17.50 \pm 0.07 \mathrm{MJ})$ diets were prepared by replacing fishmeal (FM) in the control (CT) diet with 15\% Hermetia illucens (HI) larvae meal and 15\% Tenebrio molitor (TM) larvae meal (Table 3). These three diets were referred to as the CT diet, HI diet, and TM diet. The full-fat insect meals were prepared by HiProMine S.A. (Poland). They were dried at $50^{\circ} \mathrm{C}$ for $48 \mathrm{~h}$ until they reached $95 \%$ dry matter.

In all diets, blood meal, yeasts, postextraction soybean meal, dried whey and wheat gluten were added as protein sources supplements at the same levels. The uses of these meals are approved according to EU regulations.

The diets were prepared with a cooking extrusion process using a semi-industrial single-screw extruder (type S-60, METALCHEM Gliwice, Poland). The extrusion conditions were as follows: $90^{\circ} \mathrm{C}$ cylinder temperature in the zone of increasing pressure, $100^{\circ} \mathrm{C}$ cylinder temperature in the zone of high pressure, $110^{\circ} \mathrm{C}$ head temperature, $52 \mathrm{rpm}$ speed screw and $6 \mathrm{~mm}$ nozzle diameter.

\section{Proximate composition and amino acid analysis}

Chemical analyses of the dietary ingredients were performed prior to diet formulation. Diets and their ingredients, as well as the whole fish, were analyzed according to AOAC [1] procedures. Crude protein, $(\mathrm{N} \times 6.25)$ was analyzed by the Kjeldahl method after acid digestion (Kjeltec 2300 Auto Analyser, Tecator Hogänas, Sweden). Crude lipid (CL) was extracted with methyl-ether (Soxtec 1043 extraction unit, Tecator, Sweden). Dry matter analysis was performed using the Polish Standard PN-ISO 6496 and ash analysis was performed using the Polish Standard PN-76 R 64795. For crude fiber determination, the Polish
Table 3 Ingredients and composition (\%) of experimental diets for Siberian sturgeon

\begin{tabular}{|c|c|c|c|}
\hline \multirow[t]{2}{*}{ Ingredient } & \multicolumn{3}{|c|}{ Diets } \\
\hline & $\overline{\mathrm{CT}}$ & $\mathrm{HI}$ & $\overline{T M}$ \\
\hline$\overline{\text { Fishmeal }^{a}}$ & 26 & 18.4 & $\overline{15.6}$ \\
\hline Mealworm, TM (Tenebrio molitior) ${ }^{\mathrm{b}}$ & 0 & 0 & 15 \\
\hline Black soldier fly, HI (Hermetia illucens) ${ }^{b}$ & 0 & 15 & 0 \\
\hline Red blood cells (dried) ${ }^{c}$ & 10 & 10 & 10 \\
\hline Yeasts $^{\mathrm{d}}$ & 8 & 8 & 8 \\
\hline Post-extraction soybean meal ${ }^{\mathrm{e}}$ & 10 & 10 & 10 \\
\hline Dried whey & 5 & 5 & 5 \\
\hline Wheat gluten & 7 & 7 & 7 \\
\hline Wheat meal & 19.1 & 15.9 & 17.1 \\
\hline Fixogran & 2 & 2 & 2 \\
\hline Rapeseed oil & 10.1 & 5.9 & 7.5 \\
\hline Lecithin & 0.5 & 0.5 & 0.5 \\
\hline Premix ${ }^{f}$ & 1.5 & 1.5 & 1.5 \\
\hline Vitazol $\mathrm{AD}_{3} \mathrm{E}^{\mathrm{g}}$ & 0.1 & 0.1 & 0.1 \\
\hline Choline chloride & 0.2 & 0.2 & 0.2 \\
\hline Vitamin C & 0.5 & 0.5 & 0.5 \\
\hline TOTAL \% & 100 & 100 & 100 \\
\hline
\end{tabular}

CT - control treatment - $26 \%$ of fishmeal, $\mathrm{HI}-15 \%$ of Hermetia illucens full-fat meal and $18.4 \%$ of fishmeal, TM $-15 \%$ of Tenebrio molitor full-fat meal and $15.6 \%$ of fishmeal

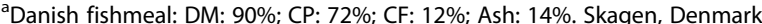

b Black soldier fly meal: DM: 97.5\%; CP: 40.4\%; CL: 33.5\%; Ash: 7.13\%. Mealworm meal: DM: 93.9\%; CP: 56.3\%; CL: 25.3\%; Ash: 4.53\%. HiProMine S.A. Poland

'Spray dried, $900 \mathrm{~g} \mathrm{~kg}^{-1}$ protein, APC Europe, Spain

'Yeast, $45 \%$ protein, $6 \%$ ash

'Solvent extracted: $45 \%$ protein

fPolfamix W, BASF Polska Ltd. Kutno, Poland - containing per $1 \mathrm{~kg}$ : vitamin A $1000000 \mathrm{IU}$, vitamin D3 200,000 IU, vitamin E $1.5 \mathrm{~g}$, vitamin K $0.2 \mathrm{~g}$, vitamin B1 $0.05 \mathrm{~g}$, vitamin B2 $0.4 \mathrm{~g}$, vitaminB12 $0.001 \mathrm{~g}$, nicotinic acid $2.5 \mathrm{~g}$, D-calcium pantothenate $1.0 \mathrm{~g}$, choline chloride $7.5 \mathrm{~g}$, folic acid $0.1 \mathrm{~g}$, methionine $150.0 \mathrm{~g}$, lysine 150.0 g, Fe 2.5 g, Mn 6.5 g, Cu 0.8 g, Co 0.04 g, Zn 4.0 g, J 0.008 g, ${ }^{9}$ Vitamin premix $\mathrm{AD}_{3} \mathrm{EC}$, BIOWET Drwalew, Poland - contains in $1 \mathrm{~kg}$ : vitamin $\mathrm{A}$ $50000 \mathrm{IU}$, vitamin $\mathrm{D}_{3} 5000 \mathrm{IU}$, vitamin E $30.0 \mathrm{mg}$, vitamin C $100.0 \mathrm{mg}$

Standard PN-EN ISO 6865 was used (Table 4). All analyses were performed in triplicate.

The amino acids of the experimental diets were analyzed by a certificated company, J.S. Hamilton S.A., Poland, where 17 amino acids were detected. The composition analysis of the experimental diets (Table 4) showed that the inclusion of insect meal did not affect the amino acid values or the relationship of essential and nonessential amino acids (EAA/NEAA), which were between 0.85 and 0.86 .

\section{Growth trial and fish sampling}

A total of 180 juvenile Siberian sturgeon $(640 \mathrm{~g} \pm 3.9)$ were used in the trial. Twenty fish were randomly distributed per tank. All animals were brought to Feed Production Technology and Aquaculture Experimental Station in Muchocin of Poznań Univeristy of 
Table 4 Chemical composition of the experimental diets, including amino acids expressed in dry matter

\begin{tabular}{|c|c|c|c|}
\hline \multirow[t]{2}{*}{ Parameter } & \multicolumn{3}{|l|}{ Diets } \\
\hline & $\mathrm{CT}$ & $\mathrm{HI}$ & TM \\
\hline Dry matter (\%) & 90.08 & 90.41 & 90.42 \\
\hline Crude protein (\%) & 53.02 & 53.21 & 53.36 \\
\hline Crude fat (\%) & 19.67 & 19.85 & 19.28 \\
\hline Crude fibre (\%) & 2.81 & 2.79 & 2.53 \\
\hline Ash (\%) & 7.49 & 7.51 & 7.48 \\
\hline Nitrogen-free-extract (\%) & 7.09 & 7.05 & 7.77 \\
\hline Energy (MJ/kg) & 17.48 & 17.57 & 17.50 \\
\hline \multicolumn{4}{|c|}{ Indispensable Amino Acids (g/100 g) } \\
\hline Arginine & 2.68 & 2.71 & 2.51 \\
\hline Histidine & 1.71 & 1.76 & 1.60 \\
\hline Isoleucine & 1.55 & 1.57 & 1.46 \\
\hline Leucine & 4.53 & 4.59 & 4.24 \\
\hline Lysine & 3.72 & 3.76 & 3.49 \\
\hline Methionine & 1.38 & 1.40 & 1.28 \\
\hline Phenylalanine & 2.52 & 2.57 & 2.38 \\
\hline Serine & 1.45 & 1.47 & 1.37 \\
\hline Threonine & 2.88 & 2.93 & 2.74 \\
\hline \multicolumn{4}{|c|}{ Dispensable Amino Acids (g/100 g) } \\
\hline Alanine & 3.10 & 3.13 & 2.91 \\
\hline Aspartic acid & 4.56 & 4.63 & 4.30 \\
\hline Cysteine & 0.38 & 0.37 & 0.38 \\
\hline Glutamic acid & 8.51 & 8.65 & 8.00 \\
\hline Glycine & 2.73 & 2.78 & 2.52 \\
\hline Proline & 2.88 & 2.94 & 2.65 \\
\hline Tyrosine & 2.23 & 2.29 & 2.11 \\
\hline$I A A D A A^{\mathrm{a}}$ & 0.85 & 0.85 & 0.86 \\
\hline
\end{tabular}

IAA Indispensable Amino Acids, DAA Dispensable Amino Acids

Life Sciences, from Acipenseridae Fish Breeding Station of the Stanisław Sakowicz Inland Fisheries Institute in Olsztyn, Poland. Prior to the feeding trial, all fish were acclimated to the experimental rearing conditions for 1 month and fed the commercial diet "Aller Silver" (45\% crude protein, CP; $15 \%$ crude lipid, CL, Aller Aqua Poland). The fish were housed in nine fiberglass tanks ( $600 \mathrm{dm}^{3}$ capacity). Each dietary treatment was performed in 3 replications, using 20 fish in each.

The experimental unit was arranged as an openflow system; the water came directly from a river and passed through a mechanical prefiltration chamber before it entered the tanks. A water heating system was not used in this experiment to best replicate natural water temperature and the dissolved oxygen variation, which are present in European aquaculture, to simulate commercial farm conditions. The water flow allowed the complete replacement of the total tank volume once per hour. During the growth tests, the mean water temperature was $19.8 \pm 1.4{ }^{\circ} \mathrm{C}$, the dissolved oxygen (Fig. 1) was $3.8 \pm 0.9 \mathrm{mg} \mathrm{O}_{2} \mathrm{dm}^{-3}$ (WTW Multi Line P4 with optical oxygen sensor FDO 924, WTW, Weilheim, Germany), and the water $\mathrm{pH}$ ranged from 6.9 to 7.2 (WTW Multi Line P3 $\mathrm{pH}$ meter, WTW, Weilheim, Germany).

Fish were fed every day with an automatic band feeder for $12 \mathrm{~h}$ per day (08:00 a.m. to 08:00 p.m.). The daily feed rations varied from 1.8 to $1.4 \%$ according to the feeding rate as outlined by Hung, Lutes, Shqueir, and Conte [33], the biomass weight and the water temperature. The sizes of rations were adjusted every 10 days based on weight monitoring and feed intake observations (Fig. 2). The trial lasted 60 days. During this time, the daylight length was from 16:55 to $13: 21 \mathrm{~h}$.

All fish were weighed at 10-day intervals according to Mazurkiewicz et al. (2010) [54]. Prior to weighing, the fish were anesthetized by immersion in $130 \mathrm{mg} / \mathrm{L}$ tricaine methanesulfonate (MS-222, Sigma Aldrich) solution. At the end of the growth trial, all fish were individually weighed. Three animals per tank were euthanized by immersion in $500 \mathrm{mg} / \mathrm{L}$ of MS-222 solution for dissection $(n=9 /$ treatment, $n=27$ in total), all remaining animals were further maintained in the experimental station. Three intestinal tissue samples per tank were collected for histological analysis as well as for the gut microbial analysis $(n=9 /$ treatment, $n=27$ in total). During the experimental period, the following parameters were considered: mean body weight gain of individual fish (WG) expressed in grams, feed conversion ratio (FCR), specific growth rate (SGR \% day ${ }^{-1}$ ) and protein efficiency ratio (PER), which were calculated according to survival rates ( $n=3 /$ treatment, $n=9$ in total).

\section{Gastrointestinal histology}

Proximal intestine tissue samples $(n=9 /$ treatment, $n=27$ in total) were fixed in a freshly prepared formaldehyde solution $(40 \mathrm{~g} / \mathrm{L}$ of formaldehyde prepared in $0.01 \mathrm{M} \mathrm{PBS}, \mathrm{pH}=7.4$ ) immediately after dissection and incubated for $12 \mathrm{~h}$. Afterward, the samples were processed and analyzed using the methodology described in details in Rawski et al. 2016 [68]. The stained samples were visualized with Aziophot Opton light microscope at 40x magnification. The following parameters were measured: mucosal thickness, muscular layer thickness and villus height. The length of the 10 villi with complete structures were measured in 12 serial slides using a glass master micrometer (0.01 mm, PZO, Warsaw, Poland) and analyzed as the means. 


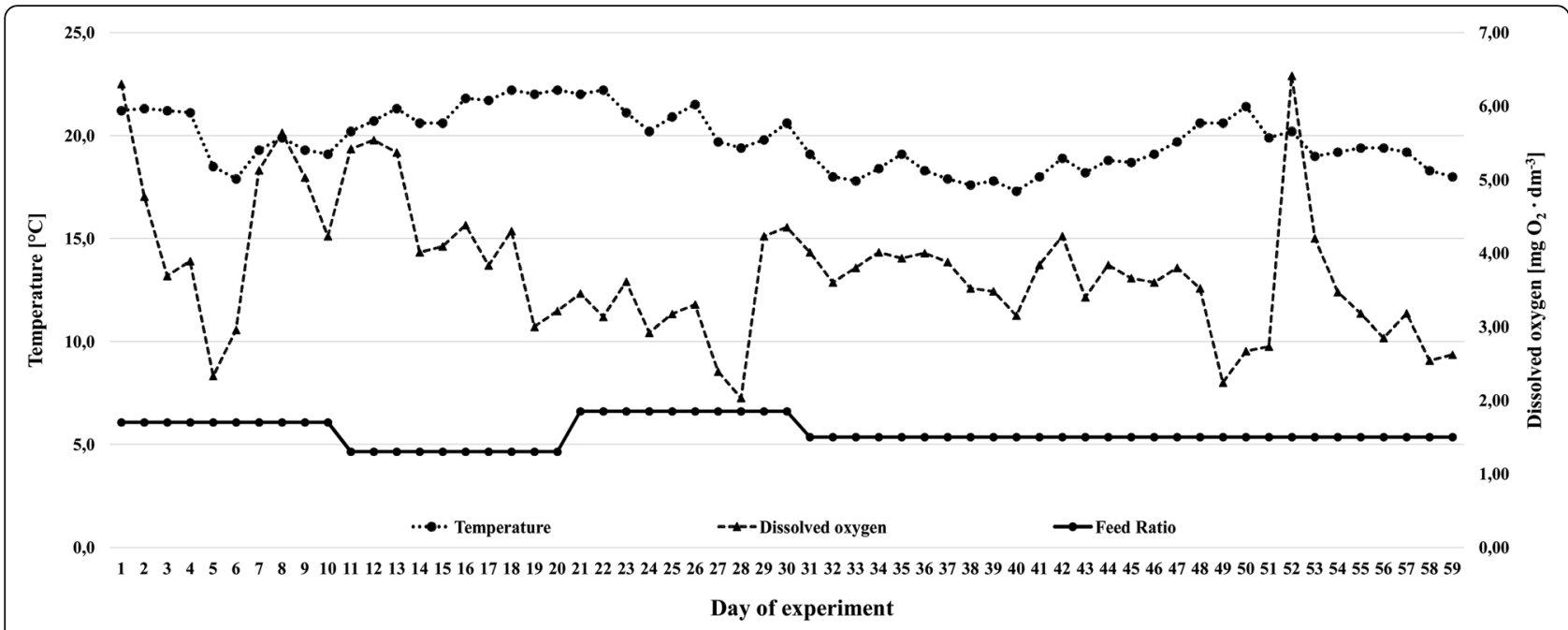

Fig. 1 Relation between temperature, dissolved oxygen, and feed ratio

\section{Microbial community analysis by fluorescent in situ} hybridization (FISH)

The samples of gastrointestinal content collected during fish dissection were immediately frozen and stored at $80{ }^{\circ} \mathrm{C}$ ( $\mathrm{n}=9 /$ treatment, $\mathrm{n}=27$ in total). The FISH and visualization procedures were performed according to Rawski et al. 2016 [68]. The oligonucleotide probes used for this study (Table 5) were selected from the literature $[19,53]$ and have been used successfully in our previous studies on poultry and turtles [38, 42, 67-69]. The numbers of detected bacteria are expressed in colony-forming units/g of digesta (CFU/ $\mathrm{ml}$ ) and were calculated according to the following equation:

$$
\log C F U / g=\log \left(N \times\left(\frac{W A}{P A}\right) \times\left(\frac{\text { Sweight }+ \text { Dweight }}{\text { Sweight }}\right) \times\left(\frac{1000}{\text { Svolume }}\right)\right)
$$

where $\mathrm{N}=$ the number of visible bacterial cells, $\mathrm{WA}=$ the work area of the filter, $\mathrm{PA}=$ the picture area, $\mathrm{S}_{\text {weight }}=$ the sample weight, $D_{\text {weight }}=$ the diluting factor weight, and $\mathrm{S}_{\text {volume }}=$ the volume of the sample pipetted onto the filter.

\section{Histomorphology of the Gastrointestinal tract}

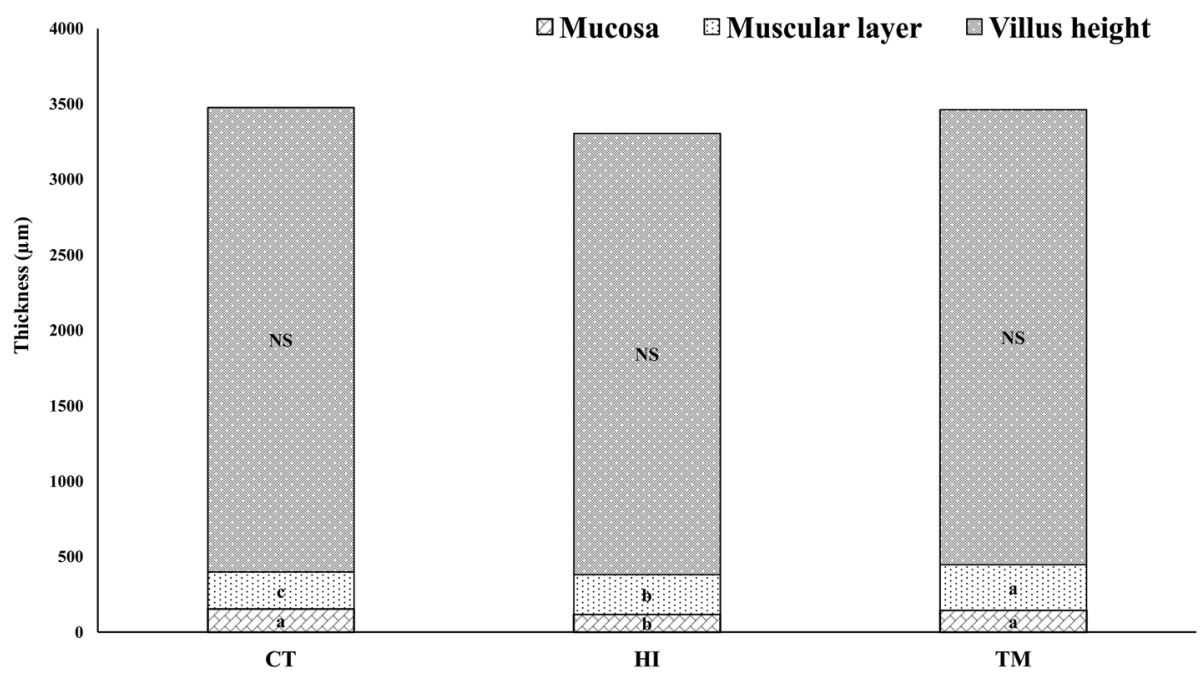

Fig. 2 Histomorphology of the proximal intestine portion of Siberian sturgeon fed with the experimental diets at the end of the 60 days $(n=12)$. Different letters indicate significant differences between treatments $(P<0.05)$ 
Table 5 Oligonucleotide probes used in fluorescent in Situ hybridization

\begin{tabular}{llll}
\hline Target & Probe & Sequence (5' to 3') & References \\
\hline Enterobacteriaceae & Enter1432 & CTTTGCAACCCACT & Sghir et al., (2000) [79] \\
Clostridium leptum subgroup & Clept1240 & GTTTRTCAACGGCAGTC & Franks et al., (1998) [19] \\
Clostridium coccoides _Eubacterium rectale cluster & Erec482 & GCTTCTTAGTCARGTACCG & Huber et al., (2004) [32] \\
Aeromonas spp. & Aer66 & CTA CTT TCC CGC TGC CGC & Salzman et al., (2002) \\
Bacillus spp. & Bmy843 & CTT CAG CAC TCA GGT TCG & Huber et al., (2004) [32] \\
Carnobacterium spp. & CAR193 & AGC CAC CTT TCC TTC AAG & Waar et al., (2005) \\
Enterococcus spp. & Enfm93 & CCG GAA AAA GAG GAG TGG C & Sghir et al.., (1998) \\
Lactobacillus group & Lab722 & YCA CCG CTA CAC ATG RAG TTC CAC T &
\end{tabular}

\section{Statistical analysis}

All data were tested for normal distribution using the Kolmogorov-Smirnov test. The analysis of variance (ANOVA) was performed. The significance of differences among the groups was determined by Duncan's multiple range test at the significance level of $P<0.05$. The following general model was used:

$$
Y_{i}=\mu+\alpha_{i}+\delta_{i j}
$$

where $Y_{i}$ is the observed dependent variable, $\mu$ is the overall mean, $\alpha_{i}$ is the effect of the diet, and $\delta_{i j}$ is the random error.

\begin{abstract}
Abbreviations
AMP: Antimicrobial peptide; AOAC: The Association of Analytical Communities; BWG: Body weight gain; CL: Crude lipid; CT: Control; EAA: Essential amino acids; FCR: Feed conversion ratio; FISH: Fluorescent in situ hybridization; FM: Fishmeal; GIT: Gastrointestinal tract; HI: Hermetia illucens; LAB: Lactic acid bacteria; MS-222: Tricaine methanesulfonate; NEAA: Nonessential amino acids; PER: Protein efficiency ratio; SBM: Soybean meal; SGR: Specific growth rate; TM: Tenebrio molitor
\end{abstract}

\section{Acknowledgements}

Not applicable

\section{Authors' contributions}

AJ: preparation of manuscript and data analysis. SNM, MR, BK, AJ: running of laboratory and statistical analysis, prepared the draft of manuscript. JM, MR, SNM: conducted and designed the experiment. All authors contributed to the analysis of the data, discussion of results and implications and commented on the manuscript at all stages. All authors read and approved the final manuscript.

\section{Funding}

This work was supported by the funds of Poznań University of Life Sciences. Co-authors employed by the funder were directly involved in interpretation of data, but not data collection, design of the study and analysis. The study was funded by TEAM TECH/2016-2/11-0026 project under the title: Insects as novel protein sources for fish and poultry, financed by the Foundation of Polish Science (POIR 4.4) and as part of the project the samples and data were collected; as well as funds of the National Center for Research and Development, no POIR.01.01.01-00-0828/15, entitled: InnSecta: innovative technology of feedstuffs production based on insect biomass plays a fundamental role in design of the study and analysis.

\section{Availability of data and materials}

All data are included in this published article. The raw datasets are available from the corresponding author on reasonable request.

\section{Ethics approval}

According to Polish law and the EU directive (no 2010/63/EU), the experiments conducted within this study did not require the formal approval of the Ethical Committee. The Local Ethical Committee for Investigations on Animals of Poznan University of Life Sciences confirmed the decision.

\section{Consent for publication}

Not applicable.

\section{Competing interests}

The authors declare that they have no competing interests.

\section{Author details}

${ }^{1}$ Department of Preclinical Sciences and Infectious Diseases, Poznan University of Life Sciences, Wołyńska, 35, 60-637 Poznań, Poland. ${ }^{2}$ Hipromine. S.A., Robakowo, Poland. ${ }^{3}$ Division of Inland Fisheries and Aquaculture, Institute of Zoology, Poznan University of Life Sciences, Wojska Polskiego 71c, 60-625 Poznań, Poland. ${ }^{4}$ Department of Animal Nutrition, Poznan University of Life Sciences, Wołyńska 33, 60-637 Poznań, Poland.

Received: 18 January 2019 Accepted: 30 August 2019

Published online: 17 October 2019

\section{References}

1. A.O.A.C. Official Methods of Analysis. Vol.I. 17th ed. Washington, DC: Association of Analytical; 2003.

2. Adil Ş, Şişman T, İncekara Ü. An investigation on the growth and reproductive performance of Poecilia reticulata (Peters) (Cyprinodontiformes: Cyprinidae) fed diets with dried insects. Mun Ent Zool. 2014;9(2):638-44.

3. Ai H, Wang F, Xia Y, Chen X, Lei C. Antioxidant, antifungal and antiviral activities of chitosan from the larvae of housefly, Musca domestica L. Food Chem. 2012;132(1):493-8.

4. Apper-Bossard E, Feneuil A, Wagner A, Respondek F. Use of vital wheat gluten in aquaculture feeds. Aquat Biosyst. 2013;9(1):21.

5. Belforti M, Gai F, Lussiana C, Renna M, Malfatto V, Rotolo L, De Marco M, Dabbou S, Schiavone A, Zoccarato I, Gasco L. Tenebrio Molitor meal in rainbow trout (Oncorhynchus mykiss) diets: effects on animal performance, nutrient digestibility and chemical composition of fillets. Ital J Anim Sci. 2015;14(4):670-6. https://doi.org/10.4081/ijas.2015.4170.

6. Biasato I, Ferrocino I, Biasibetti E, Grego E, Dabbou S, Sereno A, Gai F, Gasco L, Schiavone A, Cocolin L, Capucchio MT. Modulation of intestinal microbiota, morphology and mucin composition by dietary insect meal inclusion in free-range chickens. BMC Vet Res. 2018;14(1):383. https://doi. org/10.1186/s12917-018-1690-y.

7. Biasato I, Ferrocino I, Grego E, et al. Gut Microbiota and Mucin Composition in Female Broiler Chickens Fed Diets including Yellow Mealworm (Tenebrio molitor, L.) Animals (Basel). 2019;9(5):213. https://doi.org/10.3390/ani9050213.

8. Borrelli L, Coretti L, Dipineto L, Bovera F, Menna F, Chiariotti L, Nizza A, Lembo F, Fioretti A. Insect-based diet, a promising nutritional source, modulates gut microbiota composition and SCFAs production in laying hens. Sci Rep. 2017;7(1):16269.

9. Bronzi $\mathrm{P}$, Rosenthal $\mathrm{H}$. Present and future sturgeon and caviar production and marketing: a global market overview. J Appl Ichthyol. 2014;30(6):1536-46. 
10. Bronzi P, Chebanov M, Michaels JT, Wei Q, Rosenthal H, Gessner J. Sturgeon meat and caviar production: global update 2017. J Appl Ichthyol. 2019;35: 257-66. https://doi.org/10.1111/jai.13870.

11. De Haro C, Ramos Bueno RP, Barroso FG, Sánchez Muros MJ, Rincón Cerveza MA, Guil-Guerrero JL. Insect larvae as feed ingredient selectively increase arachidonic acid content in farmed gilthead sea bream (Sparus aurata L.). Aquac Res. 2016;47(9):2881-7.

12. Degani $G$. Availability of protein and energy from three protein sources in hybrid sturgeon Acipenser guldenstadti x A. bester. Aquac Res. 2002;33(9):725-7.

13. Egerton S, Culloty S, Whooley J, Stanton C, Ross RP. The gut microbiota of marine fish. Front Microbiol. 2018;9:873.

14. Elia AC, Capucchio MT, Caldaroni B, Magara G, Dörr AJM, Biasato I, Biasibetti E, Righetti M, Pastorino P, Prearo M, Gai F, Schiavone A, Gasco L. Influence of Hermetia illucens meal dietary inclusion on the histological traits, gut mucin composition and the oxidative stress biomarkers in rainbow trout (Oncorhynchus mykiss). Aquaculture. 2018; 496:50-7. https://doi.org/10.1016/j.aquaculture.2018.07.009.

15. Engle CR, D'Abramo L, Ponniah AG, Slater M. Editorial, global aquaculture 2050. J World Aquac Soc. 2017;48(1):3-6.

16. Estruch G, Collado MC, Peñaranda DS, Tomás Vidal A, Jover Cerdá M, Pérez Martínez G, Martinez-Llorens S. Impact of fismeal replacement in diets for gilthead sea bream (Sparus aurata) on the gastrointestinal microbiota determined by pyrosequencing the 165 rRNA gene. PLoS One. 2015;10(8): e0136389. https://doi.org/10.1371/journal.pone.0136389.

17. Faramarzi M, Jafaryan $H$, Roozbehfar $R$, Jafari M, Rashidi Y, Biria M. Influences of probiotic bacilli via bioencapsulated Daphnia magna on resistance of Persian sturgeon larvae against challenge tests. Glob Vet. 2012;8(4):421-5.

18. Francis G, Makkar HPS, Becker K. Antinutritional factors present in plantderived alternate fish feed ingredients and their effects in fish. Aquaculture. 2001;199(3-4):197-227.

19. Franks AH, Harmsen HJM, Raangs GC, Jansen GJ, Schut F, Welling GW. Variations of bacterial populations in human feces measured by fluorescent in situ hybridization with group-specific 16S rRNA-targeted oligonucleotide probes. Appl Environ Microbiol. 1998;64(9):3336-45.

20. Ganguly S, Prasad A. Microflora in fish digestive tract plays significant role in digestion and metabolism. Rev Fish Biol Fisheries. 2012;22:11-6.

21. Gasco L, Henry M, Piccolo G, Marono S, Gai F, Renna M, Lussiana C, Antonopoulou E, Mola P, Chatzifotis S. Tenebrio molitor meal in diets for European sea bass (Dicentrarchus labrax L.) juveniles: growth performance, whole body composition and in vivo apparent digestibility. Anim Feed Sci Technol. 2016;220:34-45. https://doi.org/ 10.1016/j.anifeedsci.2016.07.003.

22. Geraylou Z, Souffreau C, Rurangwa E, De Meester L, Courtin CM, Delcour JA, Buyse J, Ollevier F. Effects of dietary arabinoxylan-oligosaccharides (AXOS) and endogenous probiotics on the growth performance, non-specific immunity and gut microbiota of juvenile Siberian sturgeon (Acipenser baerii). Fish Shellfish Immunol. 2013;35(3):766-75. https:/doi.org/10.1016/.jfsi.2013.06.014.

23. Geraylou Z, Souffreau C, Rurangwa E, Maes GE, Spanier KI, Courtin CM, Delcour JA, Buyse J, Ollevier F. Prebiotic effects of arabinoxylan oligosaccharides on juvenile Siberian sturgeon (Acipenser baerii) with emphasis on the modulation of the gut microbiota using 454 pyrosequencing. FEMS Microbiol Ecol. 2013;86(2):357-71. https://doi.org/10.1111/1574-6941.12169.

24. Ghosh K, Roy M, Kar N, Ringo E. Gastrointestinal bacteria in rohu, Labeo rohita (Actinopterygii: Cyprini-formes: Cyprinidae): scanning electron microscopy and bacteriological study. Acta Ichthyol Piscat. 2010;40(2):12935. https://doi.org/10.3750/AIP2010.40.2.05.

25. Gisbert E, Ruban Gl. Ontogenetic behavior of Siberian sturgeon, Acipenser baerii: a synthesis between laboratory tests and field data. Environ Biol Fish. 2003;67(3):311-9.

26. Gotesman M, Menanteau-Ledouble S, Saleh M, Bergmann SM, El-Matbouli M. A new age in AquaMedicine: unconventional approach in studying aquatic diseases. BMC Vet Res. 2018;14(1):178. https://doi.org/10.1186/s12917-018-1501-5.

27. Guerrerio I. Oliva-Teles a, Enes P. prebiotics as functional ingredients: focus on Mediterranean fish aquaculture. Rev Aquacult. 2018;10(4):80032. https://doi.org/10.1111/raq.12201

28. Guilbard F, Munro J, Dumont P, Hatin D, Fortin R. Feeding ecology of Atlantic sturgeon and Lake sturgeon co-occuring in the St. Lawrence estuarine transition zone. Am Fish Soc Symp. 2007:56:85-104.

29. Heinritz SN, Weiss E, Eklund M, Aumiller T, Louis S, Rings A, et al. Intestinal microbiota and microbial metabolites are changed in a pig model fed a highfat/low-fiber or a low-fat/high-fiber diet. PLoS One. 2016;11(4): e0154329. https://doi.org/10.1371/journal.pone.0154329.
30. Henry M, Gasco L, Piccolo G, Fountoulaki E. Review on the use of insects in the diet of farmed fish: past and future. Anim Feed Sci Technol. 2015;203:122. https://doi.org/10.1016/j.anifeedsci.2015.03.001

31. Hoover JJ, George SG, Killgore KJ. Diet of shovelnose sturgeon and pallid sturgeon in the free-flowing Mississippi River. J Appl Ichthyol. 2007;23(4): 494-9. https://doi.org/10.1111/j.1439-0426.2007.00893.x.

32. Huber I, Spanggaard B, Appel KF, Rossen L, Nielsen T, Gram L. Phylogenetic analysis and in situ identification of the intestina microbial community of rainbow trout (Oncorhynchus mykiss, Walbaum). J Appl Microbiol. 2004;96(1):117-32.

33. Hung SSO, Lutes PB, Shqueir AA, Conte FS. Effect of feeding rate and water temperature on growth of juvenile white sturgeon (Acipenser transmontanus). Aquaculture. 1993:115(3-4):297-303.

34. Huntington TC, Hasan MR. Fish as feed inputs for aquaculture - practices, sustainability and implications: a global synthesis. In: Hasan MR, Halwart M, editors. Fish as feed inputs for aquaculture: practices, sustainability and implications, vol. 518. Rome: FAO: fisheries and aquaculture technical paper; 2009. p. 1-61.

35. Imanpoor MR, Bagheri T. Effects of replacing fish meal by soybean meal along with supplementing phosphorus and magnesium in diet on growth performance of Persian sturgeon, Acipenser persicus. Fish Physiol Biochem. 2012:38(2):521-8. https://doi.org/10.1007/s10695-011-9532-x.

36. Jabir MDAR, Razak SA, Vikineswary S. Chemical composition and nutrient digestibility of super worm meal in red tilapia juvenile. Pak Vet J. 2012;32(4):489-93.

37. Jahanbakhshi A, Imanpour M, Taghizadeh V, Shabani A. Effects of replacing fish meal with plant protein (sesame oil cake and corn gluten) on growth performance, survival and carcass quality of juvenile beluga (Huso huso). World J Fish Mar Sci. 2012;4(4):422-5.

38. Józefiak A, Nogales-Mérida S, Mikołajczak Z, Rawski M, Kierończyk B, Mazurkiewicz J. The utilization of full-fat insect meal in rainbow trout (Oncorhynchus mykiss) nutrition: the effects on growth performance, intestinal microbiota and gastro-intestinal tract histomorphology. Ann Anim Sci. 2019. https://doi.org/10.2478/aoas-2019-0020 (ahead-of-print).

39. Józefiak A, Engberg RM. Insect proteins as a potential source of antimicrobial peptides in livestock production. A review. J Anim Feed Sci. 2017;26(2):87-99. https://doi.org/10.22358/jafs/69998/2017.

40. Józefiak A, Kierończyk B, Rawski M, Mazurkiewicz J, Benzertiha A, Gobbi P, NogalesMerida S, Świątkiewicz S, Józefiak D. Full-fat insect meals as feed additive - the effect on broiler chicken growth performance and gastrointestinal tract microbiota. J Anim Feed Sci. 2018;27:131-9. https://doi.org/10.22358/jafs/91967/2018.

41. Józefiak D, Józefiak A, Kierończyk B, Rawski M, Świątkiewicz S, Długosz J, Engberg RM. Insects - a natural nutrient source for poultry - a review. Ann Anim Sci. 2016;16(2):297-313. https://doi.org/10.1515/aoas-2016-0010.

42. Józefiak D, Kierończyk B, Juśkiewicz J, Zduńczyk Z, Rawski M, Długosz J, Sip A, Højberg O. Dietary Nisin modulates the gastrointestinal microbial ecology and enhances growth performance of the broiler chickens. PLoS One. 2013; 8(12):e85347. https://doi.org/10.1371/journal.pone.0085347.

43. Józefiak D, Sip A, Rawski M, Rutkowski A, Kaczmarek S, Hojberg O, Jense BB, Engberg RM. Dietary divercin modifies gastrointestinal microbiota and improves growth performance in broiler chickens. Br Poult Sci. 2011;52(4): 492-9. https://doi.org/10.1080/00071668.2011.602963.

44. Kabeerdoss J, Sankaran V, Pugazhendhi S, Ramakrishna BS. Clostridium leptum group bacteria abundance and diversity in the fecal microbiota of patients with inflammatory bowel disease: a case-control study in India. BMC Gastroenterol. 2013;13:20. https://doi.org/10.1186/1471-230X-13-20.

45. Keevin TM, George SG, Hoover JJ, Kuhajda BR, Mayden RL. Food habits of the endangered Alabama sturgeon, Scaphirhynchus suttkusi Williams and Clemmer, 1991 (Acipenseridae). J Appl Ichthyol. 2007;23(4):500-5. https:// doi.org/10.1111/j.1439-0426.2007.00906.x.

46. Khajepour F, Hosseini SA. Calcium and phosphorus status in juvenile Beluga (Huso huso) fed citric acid-supplemented diets. Aquac Res. 2011;43(3):40711. https://doi.org/10.1111/j.1365-2109.2011.02843.x.

47. Kittel EC, Sealey WM, Small BC. Preliminary investigation of dietary soy sensitivity in shovelnose sturgeon. J Appl Aquac. 2014;26(4):356-69. https:// doi.org/10.1080/10454438.2014.965397.

48. Li S, Ji H, Zhang B, Zhou J, Yu H. Defatted black soldier fly (Hermetia illucens) larvae meal in diets for juvenile Jian carp (Cyprinus carpio var. Jian): growth performance, antioxidant enzyme activities, digestive enzyme activities, intestine and hepatopancreas histological structure. Aquaculture. 2017:477: 62-70. https://doi.org/10.1016/j.aquaculture.2017.04.015.

49. Ma N, Guo P, Zhang J, He T, Kim SW, Zhang G, Ma X. Nutrients mediate intestinal bacteria-mucosal immune crosstalk. Front Immunol. 2018;9:5. 
50. Magalhães R, Sánchez-López A, Silva Leal R, Martínez-Llorens S, Oliva-Teles A, Peres $\mathrm{H}$. Black soldier fly (Hermetia illucens) pre-pupae meal as a fish meal replacement in diets for European seabass (Dicentrarchus labrax). Aquaculture. 2017;476:79-85. https:/doi.org/10.1016/j.aquaculture.2017.04.021.

51. Makkar HPS, Tran G, Heuzé V, Ankers P. State-of-the-art on use of insects as animal feed. Anim Feed Sci Technol. 2014;197:1-33. https://doi.org/10. 1016/j.anifeedsci.2014.07.008

52. Manson JM, Rauch M, Gilmore MS. (2008). The commensal microbiology of the grastrointestinal tract. In: Huffnagle GB, Noverr NC, editors. Gl microbiota and regulation of the immune system New York, U.S.a: springer science+business media, LLC, Landes Bioscience; 2008. p. 15-28.

53. Manz W, Szewzyk U, Ericsson P, Amann R, Schleifer KH, Stenström TA. In situ identification of bacteria in drinking water and adjoining biofilms by hybridization with 165 and 235 rRNA-directed fluorescent oligonucleotide probes. Appl Environ Microbiol. 1993;59(7):2293-8.

54. Mazurkiewicz J, Przybył A, Czyżak-Runowska G, Łyczyński A. Cold-pressed rapeseed cake as a component of the diet of common carp (Cyprinus carpio L.): effects on growth, nutrient utilization, body composition and meat quality. Aquac Nutr. 2010;17(4):387-94

55. Mazurkiewicz J, Przybył A, Golski J. Usability of some plant protein ingredients in the diets of Siberian sturgeon Acipenser baerii Brandt. Arch Pol Fish. 2009;17:45-52. https://doi.org/10.2478/v10086-009-0002-3.

56. Miles RD, Chapman FA. The benefits of fish meal in aquaculture diets. IFAS extension, University of Florida, reviewed February 2018; 2006.

57. Minghetti M, Drieschner C, Bramaz N, Schug H, Schirmer K. A fish intestina epithelial barrier model established from the rainbow trout (Oncorhynchus mykiss) cell line, RT gut GC. Cell Biol Toxicol. 2017;33(6):539-55. https://doi. org/10.1007/s10565-017-9385-x

58. Muin H, Taufek NM, Kamarudin MS, Razak SA. Growth performance, feed utilization and body composition of Nile tilapia, Oreochromis niloticus (Linnaeus, 1758) fed with different levels of black soldier fly, Hermetia illucens (Linnaeus, 1758) maggot meal diet. Iran J Fish Sci. 2017;16(2):567-77.

59. Nayak SK. Probiotics and immunity: a fish perspective. Fish Shellfish Immunol. 2010;29(1):2-14. https://doi.org/10.1016/j.fsi.2010.02.017.

60. Ng WK, Liew FL, Ang LP, Wong KW. Potential of mealworm (Tenebrio molitor) as an alternative protein source in practical diets for African catfish, Clarias gariepinus. Aquac Res. 2001;32(1):273-80. https:/doi.org/10.1046/j.1355-557x.2001.00024x.

61. Nogales-Mérida S, Gobbi P, Józefiak D, Mazurkiewicz J, Dudek K, Rawski M, Kierończyk B, Józefiak A. Insect meals in fish nutrition. Rev Aquacult. 2018:124. https://doi.org/10.1111/raq.12281.

62. Novotny L, Dvorska L, Lorencova A, Beran V, Pavlik I. Fish: a potential source of bacterial pathogens for human beings. Vet Med - Czech. 2004;49(9):343-58.

63. Palm NW, de Zoete MR, Flavell RA. Immune-microbiota interactions in health and disease. Clin Immunol. 2015;159(2):122-7. https://doi.org/10.1016/j.clim.2015.05.014.

64. Pilet MF, Dousset X, Barre R, Novel R, Desmazeaud M, Piard JC. Evidence for two bacteriocins produced by $\mathrm{Cb}$. piscicola and $\mathrm{Cb}$ divergens isolated from fish and active against listeria monocytogenes. J Food Prot. 1995;58:256-62. https://doi.org/10.4315/0362-028X-58.3.256.

65. Praveen PK, Debnath C, Shekhar S, Dalai N, Ganguly S. Incidence of Aeromonas spp. infection in fish and chicken meat and its related public health hazards: a review. Vet World. 2016;9(1):6-11. https://doi.org/10.14202/vetworld.2016.6-11.

66. Pryor GS, Royes JB, Chapman FA, Miles RD. Mannanoligosaccharides in fish nutrition: effects of dietary supplementation on growth and gastrointestinal villi structure in Gulf of Mexico sturgeon. N Am J Aquac. 2003;65(2):106-11. https://doi.org/10.1577/1548-8454(2003)65<106:MIFNEO>2.0.CO:2.

67. Ptak A, Bedford MR, Świątkiewicz S, Żyła K, Józefiak D. Phytase modulates lleal microbiota and enhances growth performance of the broiler chickens. PLoS One 2015;10(3):e0119770. https:/doi.org/10.1371/journal.pone.0119770.

68. Rawski M, Kierończyk B, Długosz J, Świątkiewicz S, Jozefiak D. Dietary probiotics affect gastrointestinal microbiota, histological structure and shel mineralization in turtles. PloS ONE. 2016;11(2):e0147859. 2016. https://doi. org/10.1371/journal.pone.0147859.

69. Rawski M, Kierończyk B, Świątkiewicz S, Jozefiak D. Long-term study on single and multiple species probiotic preparations for Florida softshell turtle (Apalone ferox) nutrition. Anim. Sci. Rep. 2018;36(1):87-98.

70. Renna M, Schiavone A, Gai F, Dabbou S, Lussiana C, Malfatto V, Prearo M, Capucchio MT, Biasato I, Biasibetti E, De Marco M, Brugiapaglia A, Zoccarato I, Gasco L. Evaluation of the suitability of a partially defatted black soldier fly (Hermetia illucens L.) larvae meal as ingredient for rainbow trout (Oncorhynchus mykiss Walbaum) diets. J Anim Sci Biotechnol. 2017:8:57. https://doi.org/10.1186/s40104-017-0191-3.
71. Ringø $E$, Olsen RE. The effect of diet on aerobic bacterial flora associated with intestine of Arctic charr (Salvelinus alpinus L.). J Appl Microbiol. 1999; 86(1):22-8. https://doi.org/10.1046/j.1365-2672.1999.00631.x.

72. Ringø E, Strøm E. Microflora of Arctic charr, Salvelinus alpinus (L.): gastrointestinal microflora of free-living fish and effect of diet and salinity on intestinal microflora. Aquac Fish Manag. 1994;25(6):623-30. https://doi. org/10.1111/j.1365-2109.1994.tb00726.x.

73. Roncarati A, Gasco L, Parisi G, Terova G. Growth performance of common catfish (Ameiurus melas Raf.) fingerlings fed mealworm (Tenebrio molitor) diet. J Insects Food Feed. 2015;1(3):233-40. https://doi.org/10.3920/JIFF2014.0006.

74. Rónyai A, Csengeri I, Váradi L. Partial substitution of animal protein with fullfat soybean meal and amino acid supplementation in the diet of Siberian sturgeon (Acipenser baerii). J Appl Ichthyol. 2002;18(4-6):682-4. https://doi. org/10.1046/j.1439-0426.2002.00372.x

75. Salzman $\mathrm{NH}$, de Jong $\mathrm{H}$, Paterson $\mathrm{Y}$, Harmsen $\mathrm{HJ}$, Welling GW, Bos NA. Analysis of 165 libraries of mouse gastrointestinal microflora reveals a large new group of mouse intestinal bacteria. Microbiology. 2002 Nov;148:365160. https://doi.org/10.1099/00221287-148-11-3651.

76. Santigosa E, Sánchez J, Medale F, Kaushik S. Pérez-Sánchez J, Gallardo MA. Modifications of digestive enzymes in trout (Oncorhynchus mykiss) and sea bream (Sparus aurata) in response to dietary fish meal replacement by plant protein sources. Aquaculture. 2008;282(1-4):68-74. https://doi.org/10.1016/j.aquaculture.2008.06.007.

77. Sarvestani FS, Rahmanifar R, Tamadon A. Histomorphometric changes of small intestine in pregnant rat. Vet Res Forum. 2015;6(1):69-73.

78. Seeley R, Stephens T, Tate P. Digestive System. In: Anatomy and Physiology. 6th ed: The McGraw-Hill Companies; 2004. p. 859-910. http://bio.bsu.by/t/ temp/holik/24\%20Digestive\%20System.pdf.

79. Sghir A, Gramet G, Suau A, Rochet V, Pochart P, Dore J. Quantification of bacterial groups within human fecal flora by oligonucleotide probe hybridization. Appl Environ Microbiol. 2000;66(5):2263-6.

80. Stamer A, Wesselss S, Neidigk R, Hoerstgen-Schwark G. Black soldier fly (Hermetia illucens) larvae-meal as an example for a new feed ingredients 'class in aquaculture diets. Proceedings of the 4th ISOFAR Scientific Conference. Istanbul: "Building Organic Bridges" at the Organic World Congress; 2014.

81. Ustaoglu S, Rennert B. The apparent nutrient digestibility of diets containing fish meal or isolated soy protein in sterlet (Acipenser ruthenus). Int Rev Hydrobiol. 2002;87(5-6):577-84. https://doi.org/10.1002/15222632(200211)87:5/6<577::AID-IROH577>3.0.CO;2-4.

82. Ventresqui Oliveira R, Costa Oliveira M, Pelli A. Disease infection by Enterobacteriaceae family in Fishes: a review. J Microbiol Exp. 2017;4(5): 00128. https://doi.org/10.15406/jmen.2017.04.00128.

83. Wagner CE, Mclntyre PB, Buels KS, Gilbert DM, Michel E. Diet predicts intestine length in Lake Tanganyika's cichlid fishes. Funct Ecol. 2009;23(6):1122-31.

84. Wang S, Zeng X, Yang Q, Qiao S. Antimicrobial peptides as potential alternatives to antibiotics in food animal industry. Int J Mol Sci. 2016;17(5): 603. https://doi.org/10.3390/ijms17050603

85. Waar K., Degener JE., van Luyn MJ., Harmsen HJ. Fluorescent in situ hybridization with specific DNA probes offers adequate detection of Enterococcus faecalis and Enterococcus faecium in clinical samples. J Med Microbiol. 2005, 54:937-44. https://doi.org/10.1099/jmm.0.46022-0.

86. Yun B, Xue M, Wang J, Sheng H, Zheng Y, Wu X, Li J. Fishmeal can be totally replaced by plant protein blend at two protein levels in diets of juvenile Siberian sturgeon, Acipenser baerii Brandt. Aquac Nutr. 2014;20(1): 69-78. https://doi.org/10.1111/anu.12053.

\section{Publisher's Note}

Springer Nature remains neutral with regard to jurisdictional claims in published maps and institutional affiliations. 